\title{
Determination of The Characteristics of Candidate Varieties Suitable for Drying
}

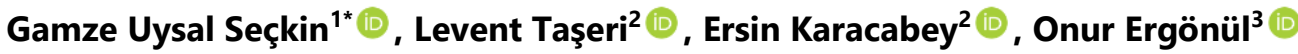 \\ ${ }^{1}$ Vitiıculture Research Institute, Food Technology Dep., Tekirdağ, Turkey. \\ ${ }^{2}$ Viticulture Research Institute, Agricultural Machinery and Data Processing Technologies Dep.,Tekirdağ, Turkey. \\ ${ }^{3}$ Viticulture Research Institute, Breeding and Genetic Resources Dep., Tekirdağ, Turkey.
}

How to cite: Seckin, G. U., Taseri, L., Karacabey, E., \& Ergönül, O. (2021). Determination of the characteristics of candidate varieties suitable for drying. Viticulture Studies (VIS), 1(1): 11 - 19. https://doi.org/10.52001/vis.2021.2

\author{
Article History \\ Received: 07.05.2021 \\ Accepted: 18.06.2021 \\ First online: 23.06 .2021
}

\section{Corresponding Author}

gamze.uysalseckin@tarimorman.gov.tr

\author{
Keywords \\ Raisin \\ Candidate varieties \\ Drying
}

\section{Introduction}

Grape is one of the most common cultivated plants in the world due to reasons such as not being very selective in terms of climate and soil requirements, easy propagation methods and being consumed in a wide variety of ways. Turkey is the fifth in the world in terms of vineyard area, ranks sixth in terms of production quantity. According to 2019's data, Turkey's grape production is considered to be $50 \%$ table grape, $39 \%$ drying and $11 \%$ winemust. It is great importance for our country to evaluate grape as dried fruit. While we are in the first place in the production of raisins in the world, our country is in same level with the USA in the production of seedless raisins. Turkey is the world leader in the production of raisins with seeds. Most of the raisins produced in Turkey are exported. Turkey, in return for 520 million dollars in 2019, has made about 243 thousand tons of dried grape exports (TSI, 2019).

250-300 thousand tons of seedless raisins,
Sultanas, are produced in Turkey yearly. The main seeded of raisins from Turkey, unique to a total of 100-150 thousand tons produced are varieties such as Dımışkı, Sergi Karası, Karadimrit, Besni, Ekşikara and Rumi (Çelik, 2013).

Preservation of fruits and vegetables by drying is an old preservation method used since ancient times, and sun drying has been used mostly in open areas (Bennion, 1990; Doymaz, 2003). The term drying means the removal of moisture from the foodstuff (Ratti, 2001). Thus, the moisture level of the food is lowered to a level that prevents the growth of microorganisms (Cemeroğlu, 2004). With these features, drying is the easiest and most common food preservation method for a wide variety of products.

Raisins are highly bio-useful food, which are a source of protein and carbohydrates and increasingly in demand in the world due to their iron, phosphate, calcium and other mineral substances and vitamins A, B1, B2, B6, C (Özden, 2008). Carughi (2008) stated that it is necessary 
to investigate raisins with their natural qualities due to their unique phytochemical composition and mineral resource, and they stated that raisins, like other fruits, lack fat, saturated fat and cholesterol, and they have high health protection due to their phenolic content.

Although the studies on raisins have increased in recent years due to its health benefits, it is still not at a sufficient level and number. Especially, studies on raisin varieties other than the Sultana grape variety are very few. In this study, drying and quality characteristics of some grape varieties obtained as a result of hybridization improvement studies carried out in Tekirdağ Viticulture Research Institute and Sultana seedless grape were determined.

\section{Material and Methods}

\section{Material}

In this study, 5 different varieties of grapes and Sultanas grapes were used from the new candidate varieties to be registered as a result of the breeding studies in the Tekirdağ Viticulture Research Institute trial vineyards at latitude $40.969184^{\circ}-40.973562^{\circ} \mathrm{N}$ and longitude coordinates $27.461911^{\circ}-27.477504^{\circ} \mathrm{E}$ in 2019 . Pictures of all the candidate grapes are shown in Figure 1 . Only one of the grape varieties $\left(43^{*} B\right.$ 103) studied was black, the others all were white.

Sultana: Sultana is a variety which ripens in midseason. It grows strong with conical clusters, wings, normal density, small oval shaped berries and average berry skin thickness. Although it is a variety for drying, Sultana Seedless variety is also processed as table grapes through a series of culture practice (Ateş et al., 2016).

43*B-103: It was obtained by crossing Hönüsü and Perlette cultivars. It's berries are seedless, dark-red violet and in the form of obtuse ovoid. It's berries are very small and average $2 \mathrm{~g}$. It forms dense bunches. It's yield per vine is 11.2 kilograms (Ergönül et al., 2020).

$7 * D-258$ : It was obtained by crossing Italia and Barış cultivars. It's berries are seedless, green-yellow color and globose shaped. Average berry weight is 4.8 grams. It forms medium dense bunches. It's yield per vine is about 10 kilograms (Ergönül et al., 2020).
43*B-42: It was obtained by crossing Hönüsü and Perlette cultivars. It's berries are seedless, green-yellow and globose shaped. It's berries are about 2-3 grams. It forms medium dense bunches. It's yield per vine is 8-9 kilograms (Ergönül et al., 2020).

40*D-17: It was obtained by crossing İrikara and Barış cultivars. It's berries are seedless, green-yellow color and broad ellipsoid shaped. Average berry weight is about 5-6 grams. It forms medium dense bunches. It's yield per vine is about 8-10 kilograms (Ergönül et al., 2020).

40*D-160: It was obtained by crossing İrikara and Barış cultivars in Tekirdağ Viticulture Research Institute. It's berries are seedless, green-yellow and broad ellipsoid shaped. Average berry weight is about $5 \mathrm{~g}$. Its bunches are medium density. The yield per vine is over 10 kilograms (Ergönül et al., 2020).

\section{Method}

\section{Grape harvest}

Disease-free, normal-looking grapes were collected when the grapes reached the harvest maturity depend on the variety (brix degree 22$23 \%)$. Fresh grape samples to be analyzed by extraction were brought to the laboratory. It was placed in polyethylene bags and kept in the freezer at $-20{ }^{\circ} \mathrm{C}$ until analysis was performed. Other measurements on fresh grapes were carried out on the same day without waiting in the laboratory.

\section{Raisin production}

Fruit samples were dipped into the potasa solution containing $5 \% \mathrm{~K}_{2} \mathrm{CO}_{3}$ and $0.5 \%$ high acid olive oil. Then it was left to dry in a solar collector drying system. Figure 1 shows that the photos of grape varieties both after harvesting and drying. A solar collector drying system has been used instead of open sun drying, which is the traditional method for drying grapes. The main reason for this is that the climatic conditions in Tekirdağ province are not suitable for drying when the grapes are grown. Especially in September-October, drying is getting more difficult due to the high humidity values at night and the high number of rainy days. 


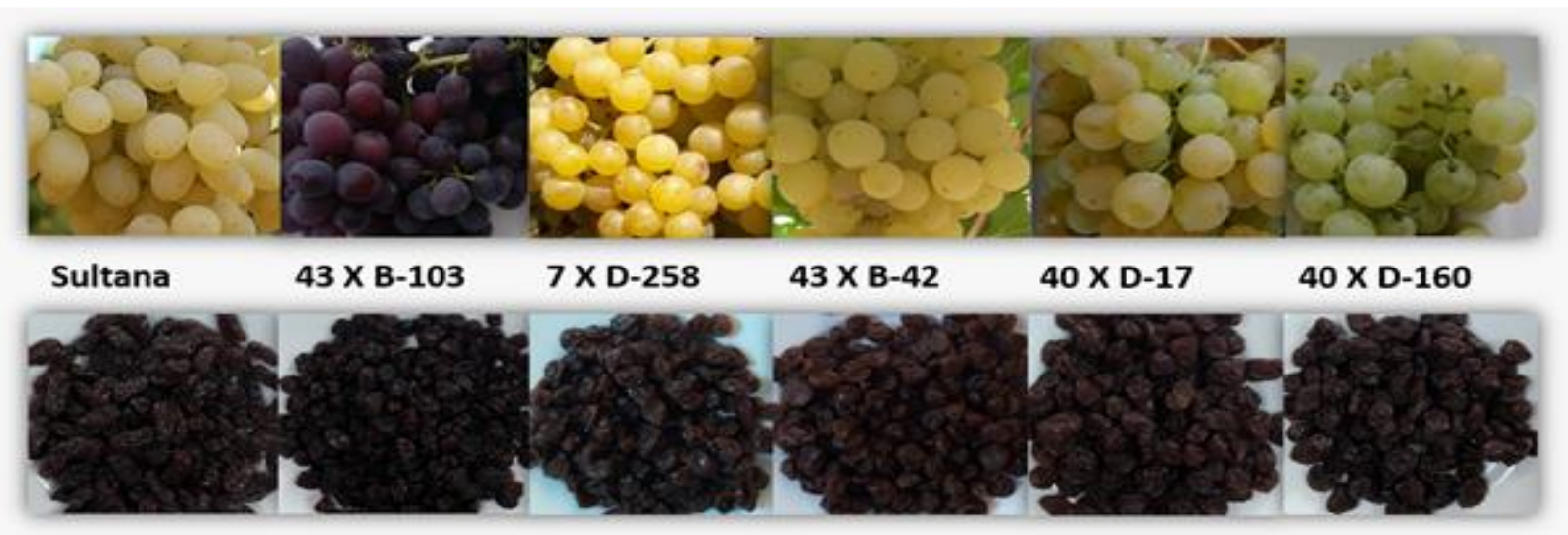

Figure 1. Photos of harvested and dried grape varieties.
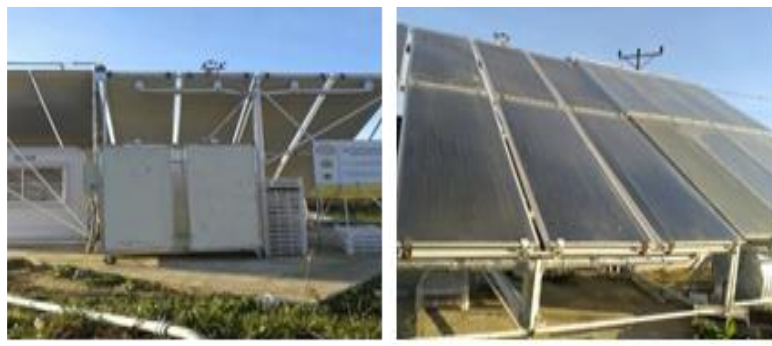

Figure 2. Solar collector drying system used in drying.

When the grape varieties reached maturity, they were dried in the solar collector drying system shown in Figure 2. The drying chamber of this solar collector consists of two compartments.

The inside size of each room is $88 \times 98 \times 194$ $\mathrm{cm}$. There are 6 trays of $59 \times 80 \mathrm{~cm}$ in the drying room. The total capacity of wet products that can be put in the drying rooms is $2 \times 120 \mathrm{~kg}$. Humidity and temperature indicators are available for each compartment. There is a control panel outside the dryer. There are 4 radial fans with a flow rate of $1700 \mathrm{~m}^{3} \mathrm{~h}^{-1}$. The internal temperature of the drying chamber was recorded continuously throughout drying.

The samples were put on the drying trays for the drying followings of the grapes.

Weight losses were measured manually in 3 replications every 3 hours.

\section{Analysis and measurements on fresh and raisin samples}

\section{Water soluble dry matter determination}

The water-soluble dry matter (brix) in the samples was determined with the help of a refractometer (Anonymous, 1983).

\section{Titration acidity determination}

A certain amount of sample was taken, a few drops of phenolphthalein ( $1 \%$ in ethanol) will be dropped and titrated with $0.1 \mathrm{~N} \mathrm{NaOH}$ solution. Results were calculated in terms of "tartaric acid" (Anonymous, 1983).

\section{Maturity index}

It was calculated by dividing the watersoluble dry matter (\%W.S.D.M) value determined in the samples by the titration acidity (\%).

\section{pH value}

The $\mathrm{pH}$ value of the samples was measured with a digital $\mathrm{pH}$ meter (Mettler Toledo FE20, Leicester, UK).

\section{Drying time and dry matter analysis}

In the drying system, the time elapsed from the beginning of drying until it reaches raisin was measured. The amount of dry matter in dry products was calculated with the help of Equation 1 by taking it out of the dryer at regular intervals and measured by their weights (Perry, 1973).

\section{Equation 1}

$$
D M 1=\frac{\text { Starting weight } \times D M 0}{\text { Final weight }}
$$

DM1: Dry matter content after drying (\%) DM0: Dry matter content of fresh fruit (\%) 


\section{Moisture content analysis}

Raisins were broken into a mixer before dry matter analysis. Before the drying process, mass of samples was measured and dried at 70 ${ }^{\circ} \mathrm{C}$ in a laboratory type vacuum oven (Nuve EV 018, Turkey) until it reachs constant mass. Then samples were placed in the desiccators for cooling to room temperature, then mass of samples were measured again. The $M C$ of the samples was specified by dividing the difference between the initial and final measurement into the initial measurement.

\section{Water activity (aw)}

Water activity is a very important factor which is regarded as a microbiological stability indicator in foodstuffs and $\mathrm{a}_{\mathrm{w}}$ can be determined by the use of the water activity device (AquaLab 4 TE Series Decagon Device, Pullman WA, USA).

\section{Color analysis}

Color analysis was performed on whole fruit in samples. Color analysis $L^{*}, a^{*}, b^{*}$, chroma and hue values were determined with KonikoMinolta CM-5 device. By using the obtained values, browning indices and total color change values of raisins were calculated according to the method of Maskan (2001). Browning Index has been shown as "BI" and calculated using the formula in Equation 2. The ' $x$ ' value in the formula was calculated according to Equation 3 by using the $L^{*}, a^{*}, b^{*}$ values obtained in color measurements.

\section{Equation 2}

$$
\begin{gathered}
B I=\frac{100(x-0.31)}{0.17} \\
\text { Equation } 3 \\
x=\frac{a+1.75 L}{5.645 L+a-3.012 b}
\end{gathered}
$$

\section{Extraction of phenolic compounds}

Raisin samples were grounded in a blender and then samples were placed in a eppendorf tube, were weighed, then were added an extraction solvent $(80 \%$ aqueous methanol acidified with $0.1 \% \mathrm{HCl}$ ). With using a rotary shaker, the mixture was shaken (Rotator, Dragon Laboratory Instruments) at $50 \mathrm{rpm}$ and room temperature for $2 \mathrm{~h}$. Then, the extracts were centrifuged for $10 \mathrm{~min}$ at $4500 \mathrm{rpm}$ and to remove suspended materials. All extractions were performed as triple.

\section{Determination of total phenolic content (TPC)}

The TPC was specified by use of the FolinCiocalteu method with micro scale protocol (Waterhouse, 2002). Briefly, $40 \mu \mathrm{l}$ of raisin extract or gallic acid standards $\left(50-500 \mathrm{mg} \mathrm{l}^{-1}\right), 200 \mu \mathrm{l}$ of Folin-Ciocalteau reagent and $3.16 \mathrm{ml}$ of water were pipetted into a $4 \mathrm{ml}$ spectrophotometer cuvette. After 3-4 min, $600 \mu \mathrm{l}$ solution of $\mathrm{Na}_{2} \mathrm{CO}_{3}$ (20\%) were added. The content was held at room temperature for $2 \mathrm{~h}$, with using a spectrophotometer, at $765 \mathrm{~nm}$ against a blank, the absorbance of the sample was determined (Shimadzu UV-Vis Mini 1240, Tokyo, Japan). TPC was specified as $\mathrm{mg}$ gallic acid equivalent per gram of dried sample (mg GAE g ${ }^{-1} \mathrm{dw}$ ).

\section{DPPH free radical scavenging activity}

For the determination of the total free radical capture capacity DPPH (2.2-diphenyl-1picrylhydrazyl), Brand-Williams et al. (1995)'s method was used and the results were given in micromoles trolox equivalent per gram of raisin $\left(\mu \mathrm{mol} \mathrm{TE} \mathrm{g}^{-1} \mathrm{dw}\right)$. A $1.95 \mathrm{ml}$ of $0.1 \mathrm{mM}$ DPPH extract solution was mixed with different volume of raisin extracts $(25-50-75 \mu \mathrm{l})$, the reaction mixture was left in the dark at room temperature for $30 \mathrm{~min}$, and then the absorbance was measured at $517 \mathrm{~nm}$ against a blank at spectrophotometer.

The blank was methanol. The percentage scavenging effect was calculated as Scavenging rate $=\left(A_{0}-A_{1} / A_{0}\right)^{*} 100$, where $A_{0}$ was the absorbance of the control (without extract) and $A_{1}$ was the absorbance in the presence of the extract. The concentrations of Trolox for the calibration curve were ranged by $20-1000 \mu \mathrm{M}$.

\section{Sensory analysis}

Sensory evaluation was carried out with 6 panelists in raisin samples with the Quantitative 
Identification Analysis (QDA) of the International Standards Organization (ISO) ISO 4121: 2003 standard. Panelists made markings on a $100 \mathrm{~mm}$ long linear scale for 7 sensory parameters (color, appearance, odor, taste, hardness, chewability and total sensory effect) determined for each sample.

\section{Statistical analysis}

Experiments were conducted with three replications and results were evaluated statistically. Statistical analyses were performed by the JMP7 package program. LSD (least significant difference) test with $\mathrm{P}<0.05$ as a limit of significance was applied to data.

\section{Results and Discussion}

Dry matter amounts of the harvested grapes varied between $13.2 \%$ and $33.7 \%$. Water activity values were determined as 0.96 in all fresh grapes. The physical properties of the grape varieties at harvest time and after drying were shown at Table 1 and Table 2.

The most ripened grape was Sultana. Its water-soluble dry matter value is not very high, but since its acidity is low compared to other grapes, the ripening index is high. Since the harvest dates of the grapes were the same, their maturation was different.

$43 * B-42$ and $40 * D-160$ grapes were not dried sufficiently. During drying of these two grapes, due to the climatic effects, sufficient temperature could not be provided in the solar collector, so drying was completed before enough drying properties got. Therefor the water activities and moisture values of these raisins are higher than they should be. The amount of water that a food has and can be used by microorganisms is called as the water activity $\left.a_{w}\right)$ of that food. Microbiological stability of foods can be measured by water activity value (Demirci, 2010). Any microbiological activity is not possible in foods where the water activity value is below 0.60 . Only osmophilic yeasts can function between 0.65 and 0.60 (Mossel, 1974). In order for dry products not to spoil, water activity values should be 0.65 or less.

\section{Drying kinetics}

In order to correctly evaluate the drying kinetics of all grape varieties, we have taken into account the drying times from the same initial moisture content (75\%) to the same dry product final moisture content (20\%).

Changes of moisture content of grape samples with $75 \%$ initial moisture in collector drying until it is reduced to $20 \%$ moisture level are given in Figure 3.

The experiments were carried out between 17-24 September and the average solar radiation intensity was measured as $440 \mathrm{~W} \mathrm{~m}^{-2}$ in the weather mostly cloudy and sunny period (Figure 4). During the trials, the drying room temperature changed mostly between $30-40{ }^{\circ} \mathrm{C}$, but increased to $52{ }^{\circ} \mathrm{C}$ maximum (Figure 5).

When a statistical evaluation was made with the JMP7 package program in terms of drying times between the varieties, it was observed that there were differences between all

Table 1. Properties of harvested grape samples

\begin{tabular}{|c|c|c|c|c|}
\hline Grape variety & $\begin{array}{c}\text { Water Soluble Dry } \\
\text { Matter (\%) }\end{array}$ & $\begin{array}{c}\text { Titration Acidity } \\
\text { Determination } \\
\text { (g } 100 \mathrm{~g}^{-1} \text { tartaric acid) }\end{array}$ & Maturity Index & $\mathrm{pH}$ \\
\hline Sultana & 22.40 & 0.55 & 40.72 & 4.12 \\
\hline $43 * B-103$ & 21.80 & 0.62 & 35.16 & 3.78 \\
\hline $7 * D-258$ & 22.40 & 0.78 & 28.72 & 3.56 \\
\hline $43 * B-42$ & 21.00 & 0.84 & 25.00 & 3.41 \\
\hline $40 * D-17$ & 20.80 & 0.69 & 30.15 & 3.57 \\
\hline $40 * D-160$ & 18.00 & 0.75 & 24.00 & 3.48 \\
\hline
\end{tabular}


Table 2. Dry matter, water activity and moisture content of fresh grape and raisin samples

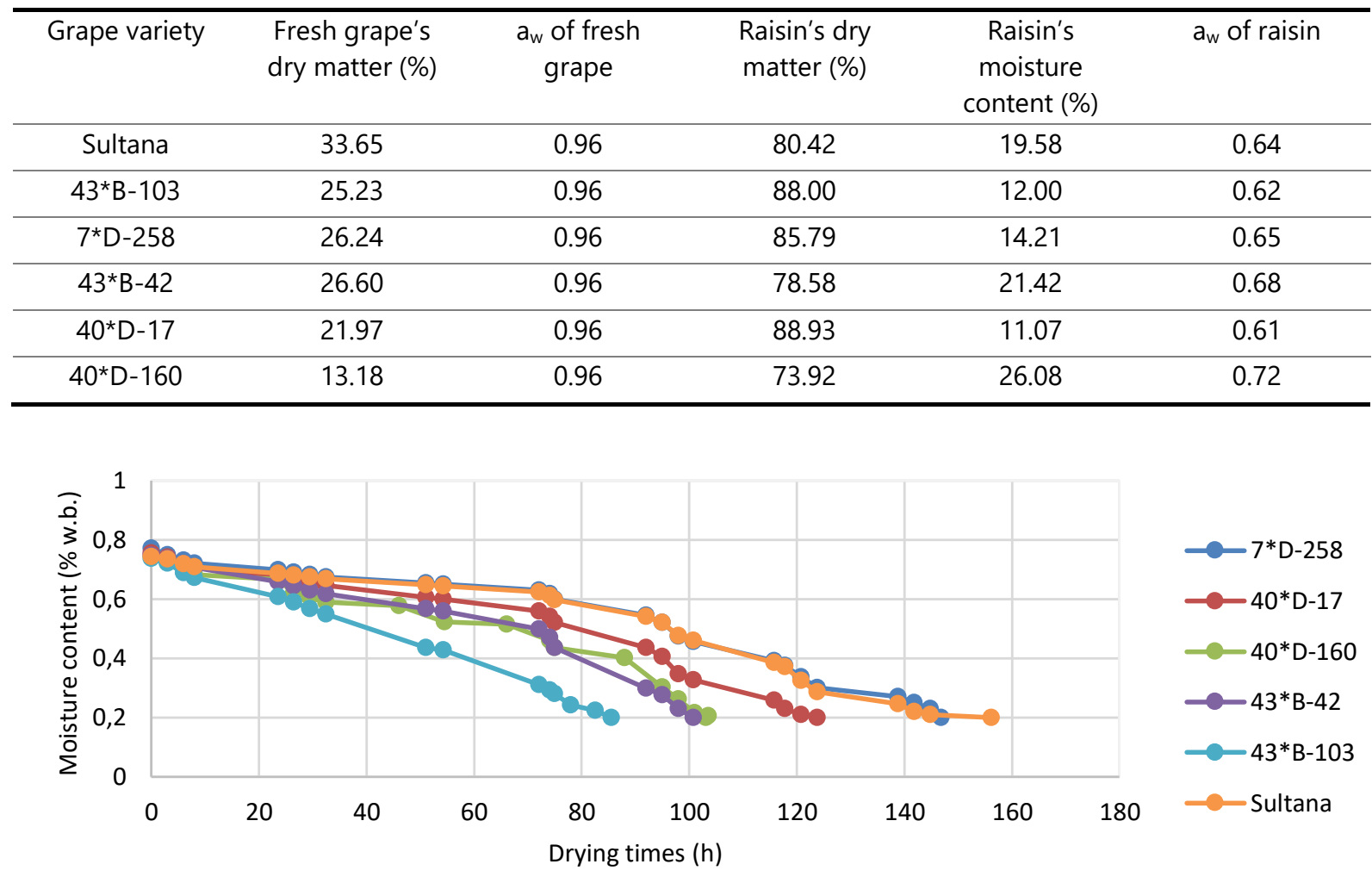

Figure 3. Change of moisture content in all varieties.

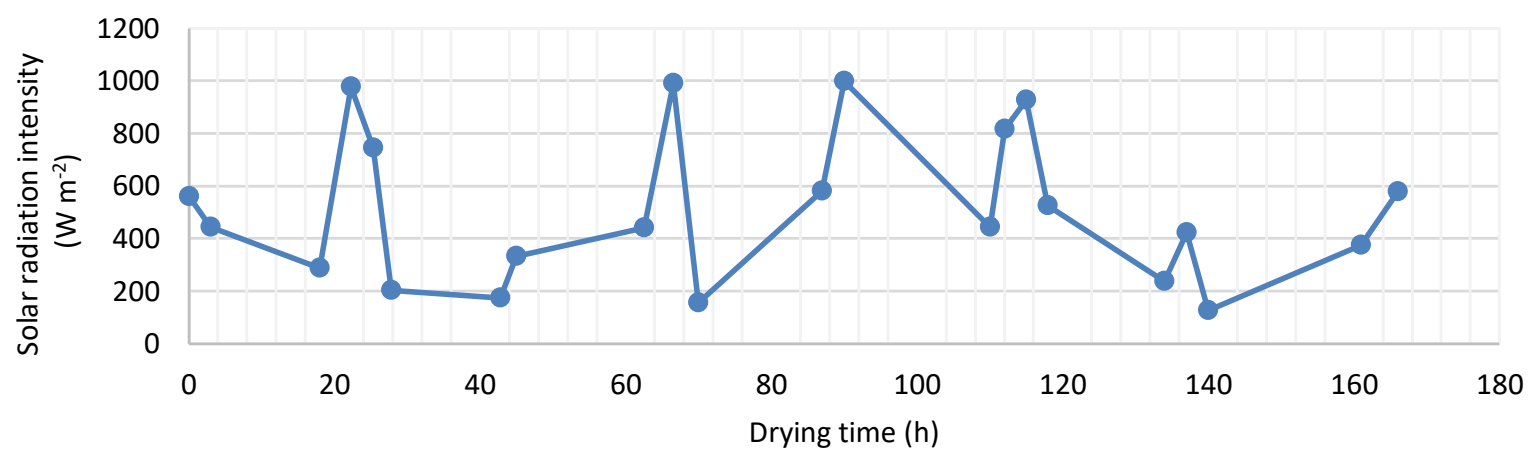

Figure 4. Changing of solar radiation intensity during drying process.

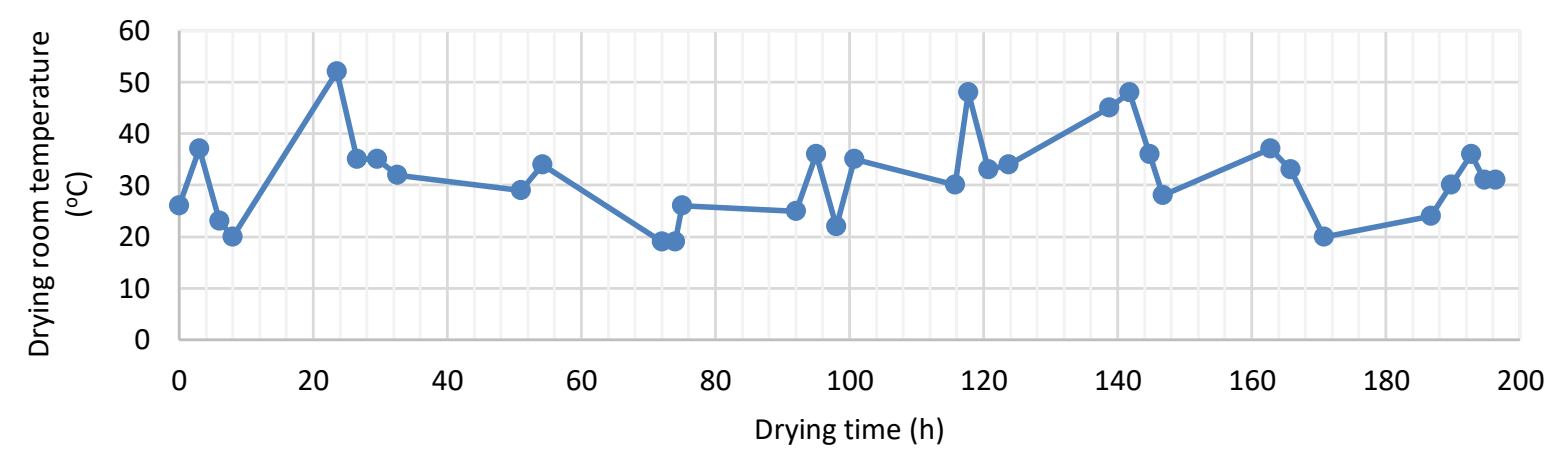

Figure 5. Change of drying room temperature during drying process. 
varieties at the level of 0.05 importance, the lowest drying time occurred as 87.28 hours in the variety candidate with the code of $43{ }^{*} \mathrm{~B}-103$ and the highest drying time occurred as 156.13 hours in Sultana seedless variety which is treated as control (Table 3). These results show that all kinds of candidates performed higher in terms of drying time than Sultana variety.

\section{Color analysis}

Color analysis of all harvested and dried

Table 3. Changing of drying time according to varieties

\begin{tabular}{cc}
\hline Grape Variety & Drying time (h) \\
\hline Sultana & $156.13^{\mathrm{a}}$ \\
\hline $43^{*} \mathrm{~B}-103$ & $87.28^{\mathrm{b}}$ \\
\hline $7^{*} \mathrm{D}-258$ & $146.21^{\mathrm{a}}$ \\
\hline $43^{*} \mathrm{~B}-42$ & $101.75^{\mathrm{b}}$ \\
\hline $40^{*} \mathrm{D}-17$ & $123.58^{\mathrm{ab}}$ \\
\hline $40^{\star} \mathrm{D}-160$ & $103.15^{\mathrm{b}}$ \\
\hline LSD $\mathrm{P}<0,05$ & 40.61
\end{tabular}

The values with different letters in a column are significantly different $(P<0.05)$ according to paired comparison through with $t$-test of the data.

Table 4. CIE L*, $a *, b$ * values, Browning Index and total color changes of grape varities

\begin{tabular}{|c|c|c|c|c|c|c|}
\hline \multicolumn{2}{|c|}{ Grape Variety } & \multirow{2}{*}{$\begin{array}{c}L^{*} \\
43.425\end{array}$} & \multirow{2}{*}{$\begin{array}{c}a^{*} \\
-1.117\end{array}$} & \multirow{2}{*}{$\begin{array}{c}b^{*} \\
5.996\end{array}$} & \multirow{2}{*}{$\begin{array}{c}\text { Browning } \\
\text { Index (BI) } \\
-\end{array}$} & \multirow{2}{*}{$\begin{array}{c}\text { Total color } \\
\text { change }(\Delta \mathrm{E}) \\
-\end{array}$} \\
\hline & Fresh grape & & & & & \\
\hline Sultana & Raisin & $30.829^{a b}$ & $2.223^{d}$ & $3.987^{b}$ & $1.85^{\mathrm{cd}}$ & $13.19^{\mathrm{a}}$ \\
\hline \multirow{2}{*}{$43 * B-103$} & Fresh grape & 35.513 & 3.719 & 2.557 & - & - \\
\hline & Raisin & $29.140^{c}$ & $2.567^{\mathrm{cd}}$ & $3.007^{c}$ & $17.08^{d}$ & $6.50^{c}$ \\
\hline \multirow{2}{*}{$7 * D-258$} & Fresh grape & 40.169 & -0.697 & 5.806 & & - \\
\hline & Raisin & $29.795^{b c}$ & $2.474^{\mathrm{cd}}$ & $4.404^{b}$ & $21.81^{c}$ & $10.96^{b}$ \\
\hline \multirow{2}{*}{$43 * B-42$} & Fresh grape & 41.495 & -0.929 & 6.219 & & - \\
\hline & Raisin & $31.276^{a}$ & $3.066^{b c}$ & $5.547^{a}$ & $26.36^{b}$ & $11.00^{b}$ \\
\hline \multirow{2}{*}{$40 * D-17$} & Fresh grape & 40.503 & -0.365 & 5.086 & & - \\
\hline & Raisin & $30.549^{a b}$ & $4.503^{a}$ & $5.789^{a}$ & $31.36^{a}$ & $11.14^{b}$ \\
\hline \multirow{2}{*}{$40 * D-160$} & Fresh grape & 40.724 & -0.646 & 4.614 & & - \\
\hline & Raisin & $31.624^{a}$ & $3.504^{b}$ & $5.566^{a}$ & $27.09^{b}$ & $10.07^{b}$ \\
\hline $\operatorname{LSD}_{(\mathrm{P}<0,05)}$ & & 1.34 & 0.59 & 0.77 & 3.26 & 1.10 \\
\hline
\end{tabular}

The values with different letters in a column are significantly different $(P<0.05)$ according to paired comparison through with $t$-test of the data.

Table 5. Bio-active property results of raisins

\begin{tabular}{ccc}
\hline Grape Variety & $\begin{array}{c}\text { Total Fenolic Content } \\
\text { mg GAE Kg }\end{array}$ & $\begin{array}{c}\text { TEAC DPPH } \\
\mu \text { mol TE g }^{-1}\end{array}$ \\
\hline Sultana & $1150^{\mathrm{bc}}$ & $1.58^{\mathrm{b}}$ \\
\hline $43^{*} \mathrm{~B}-103$ & $847^{\mathrm{cd}}$ & $1.77^{\mathrm{ab}}$ \\
\hline $7^{*} \mathrm{D}-258$ & $613^{\mathrm{d}}$ & $1.11^{\mathrm{c}}$ \\
\hline $43^{*} \mathrm{~B}-42$ & $539^{\mathrm{d}}$ & $1.10^{\mathrm{c}}$ \\
\hline $40^{*} \mathrm{D}-17$ & $1823^{\mathrm{a}}$ & $1.89^{\mathrm{ab}}$ \\
\hline $40^{*} \mathrm{D}-160$ & $1448^{\mathrm{ab}}$ & $2.05^{\mathrm{a}}$ \\
\hline $\mathrm{LSD}_{(\mathrm{P}<0,05)}$ & 383.54 & 0.44 \\
\hline
\end{tabular}

The values with different letters in a column are significantly different $(P<0.05)$ according to paired comparison through with $t$-test of the data. 
Table 6. The total sensory evaluation scores of the raisins

\begin{tabular}{lcccccccc}
\hline $\begin{array}{c}\text { Grape } \\
\text { Variety }\end{array}$ & Color & Appearance & Smell & Taste & Hardness & Chewiness & $\begin{array}{c}\text { Total } \\
\text { sensory } \\
\text { impact }\end{array}$ & Total \\
\hline Sultana & 7.60 & 7.75 & 4.58 & 6.55 & 6.58 & 7.08 & 7.10 & 47.25 \\
\hline $43 * \mathrm{~B}-103$ & 6.42 & 5.80 & 5.82 & 5.98 & 6.02 & 6.60 & 6.33 & 42.97 \\
\hline $7 * \mathrm{D}-258$ & 4.23 & 4.12 & 5.30 & 6.28 & 6.40 & 5.95 & 6.02 & 38.30 \\
\hline $43 * \mathrm{~B}-42$ & 5.00 & 5.17 & 4.95 & 5.78 & 6.13 & 5.80 & 5.72 & 38.55 \\
\hline $40 * \mathrm{D}-17$ & 5.05 & 5.25 & 5.13 & 4.37 & 5.97 & 5.92 & 5.35 & 37.03 \\
\hline $40 * \mathrm{D}-160$ & 4.72 & 4.32 & 4.77 & 4.12 & 6.00 & 5.32 & 4.83 & 34.07 \\
\hline
\end{tabular}

grape samples were made and $\mathrm{CIE} \mathrm{L}^{*}, \mathrm{a}^{*}, \mathrm{~b}^{*}$ value obtained for each grape variety were given in Table 4. Using these color values, browning indices were determined and total color changes were examined. While the most color change was in the Sultana variety, the most browned variety was $40 * D-17$. Browning in raisins is not highly desirable, with the least browning and also the least discoloration in the $43 * \mathrm{~B}-103$ variety. Since the color of the $43^{*} \mathrm{~B}-103$ grape variety is black in fresh grapes, so the color change is minimal and at the same time the $L^{*}$ value is lower. Since there was browning in colors during drying, at $L^{*}$ value's there was no differece fromthe others as raisin.

\section{Bio-active properties of raisins}

The total amounts of phenolic matter in the candidate varieties ranged from 539 to 1823 mg GAE kg-1, showing significant differences between varieties (Table 5). The highest value belongs to the $40^{*} \mathrm{D}-17$ variety. The phenolic content of the $40^{*} \mathrm{D}-17$ and $40^{*} \mathrm{D} 160$ varieties is higher than the Sultana variety. At the same time, antioxidant activity values of these varieties were determined to be higher. Fabani et al. (2017), in their study on 4 different grapes in Argentina, determined the total amount of phenolic substances between 1540-2010 mg GAE kg-1 DW. Breksa et al. (2009) found the total amount of phenolic matter they made in 16 different raisins between 3163 and $11413 \mathrm{mg}$ gallic acid $\mathrm{kg}^{-1} \mathrm{DW}$. Differences between varieties may arise from the characteristics of the variety, the climatic characteristics of the region where they grow, the soil characteristics, and the differences in cultural processes.

\section{Sensory analysis}

When the sensory analysis results were examined, Sultana and $433^{*} \mathrm{~B}-103$ grape varieties were selected as the most admired varieties (Table 6 ). The least admired variety was $40^{*} \mathrm{D}$ 160. $43 * B-103$ variety surpassed Sultana in the sensory analysis scores in the smell section, but received a lower score in appearance. It was generally accepted by the panelists for this kind of candidate, whose sensory score is closest to Sultana.

\section{Conclusion}

Sultana is the most dried grape variety all over the world. In regions where Sultana can not be grown, there is a need for different grape varieties with different characteristics, can be used for drying. Generally, the bioactive component properties of Sultana grapes are low, where two of the candidate varieties $\left(40^{*} \mathrm{D}-17\right.$ and $\left.40^{*} D-160\right)$ are better. At the same time, these two grapes dry in a shorter time than Sultana. The $43^{*} \mathrm{~B}-103$ variety candidate, which is the second in sensory evaluation score and has the least drying time, stands out with the least color change and the lowest browning index. It is very important to evaluate drying kinetics and food quality parameters together for determination of suitable candidate varieties for drying. In this study, these specifications were examined altogether and three candidate varieties showed hopeful drying characteristics. 
Also, this research was carried out in a period in which ambient temperature and solar radiation values were not high. This result reveals that these hopeful candidate varieties have also advantages in terms of drying kinetics and possible lower energy consumption result of shorter drying time.

\section{Acknowledgments}

The authors would like to thank Tekirdağ Viticulture Research Institute Directorate for providing land and laboratory facilities for this study, as well as Ilkay Biberci and Taha Güngör for assisting in laboratory studies.

\section{References}

Anonymous (1983). Food Inspection and Analysis Methods Book. T.R. Ministry of Agriculture, Forestry and Rural Affairs, General Directorate of Food Affairs. General Publication No: 65, Special Publication p. 62-105. Ankara.

Ateş, F., Ünal, A., Takma, C., \& Altındişli, A. (2016). Effects of Different Level of Leaf Removal Applications on Mineral Substance of Raisins in Organic Sultani Çekirdeksiz Grape Growing. BiO Web of Conferences 7, 01003. $39^{\text {th }}$ World Congress of Vine and Wine. doi.org/10.1051/bioconf/20160701003.

Bennion, M. (1990). Introductory Foods. Macmillan Publishing Company, ISBN0 0-02-308181-3, p. 598.

Brand-Williams, W., Cuvelier, M. E., Berset, C. (1995). Antioxidative activity of phenolic composition of commercial extracts of sage and rosemary. Food Science Technology, 28, 25-30. https://doi.org/10.1016/S0023$\underline{6438(95) 80008-5}$

Breksa, A. P., Takeoka, G. R., Hidalgo, M. B., Vilches, A., Vasse, J., \& Ramming, D. W. (2009). Antioxidant Activity And Phenolic Content Of 16 Raisin Grape (Vitis Vinifera L.) Cultivars And Selections. Food Chemistry, 121, 740-745. doi.org/10.1016/i.foodchem.2010.01.029

Carughi, A. (2008). Health Benefits of Sun-Dried Raisins; Review Of The Scientific Literature. Health Research \& Studies Center. http://www.raisins.net/Raisins and Health 200810.pdf. Access: 23.04.2021

Cemeroğlu, B. (2004). Meyve Sebze İşleme Teknolojisi, 2. cilt. ISBN 975-98578-2-0

Çelik, H. (2013). Viticulture in Turkey. Viticulture Vision 2023 Workshop. Tekirdağ Viticulture Research Institute. p. 26-27 June 2013. Cem Matbaa, Tekirdağ.

Demirci, M. (2010). Gıda Kimyası. Gıda Teknolojisi Derneği Yayınları, No: 40, p.136, İstanbul.

Doymaz, I. (2003). Convective air drying characteristics of thin layer carrots. Journal of Food Engineering, 61, 359364. doi.org/10.1016/S0260-8774(03)00142-0

Ergönül, O., Özer, C., Orhan Özalp, Z., Uysal, T., \& Sağlam, M. (2020). The development of new early and late maturing table grape cultivars by cross-breeding (Section 2). Project result report, Viticulture Research Institute, Tekirdağ.

Fabani, M. P., Baroni, M. V., Luna, L., Lingua, M. S., Monferran, M. V., Paños, H., \& Feresin, G. E. (2017). Changes in the phenolic profile of Argentinean fresh grapes during production of sun-dried raisins. Journal of Food Composition and Analysis, 58, 23-32. doi.org/10.1016/j.jfca.2017.01.006

ISO 4121 (2003). Sensory analysis - methodology. Guidelines for the use of quantitative response scales. International Organization for Standardization. https://www.iso.org/standard/33817.html. Access: 25.03.2021

Maskan, M. (2001). Drying, shrinkage and rehydration characteristics of kiwifruits during hot air and microwave drying. Journal of Food Engineering, 48, 177-182. doi.org/10.1016/S0260-8774(00)00155-2

Mossel, D. A. A. (1974). Water and Micro-organisms in Foods- A Synthesis, Food Science and Techonology, p. 347. Özden, C. (2008). Raisin. T.R. Prime Ministry Undersecretariat of Foreign Trade Export Development Study Center. Perry, J. H. (1973). Drying, Chemical Engineerings' Handbook. Mc Graw-Hill Co.,Inc. Newyork, 15, 33-50.

Ratti, C. (2001). Hot-air and Frezee-drying of High Value Foods: A Review. Journal of Food Engineering, 49, $311-$ 319. doi.org/10.1016/S0260-8774(00)00228-4

TSI (2019). Quantities of raisin export in 2019. Turkish Statistical Institue Data Portal for Staticts. https://data.tuik.gov.tr/Kategori/GetKategori?p=tarim-111\&dil=1. Access: 22.04 .2021

Waterhouse, A. L. (2002). Determination of total phenolics. Current protocols in food analytical chemistry. https://doi.org/10.1002/0471142913.fai0101s06 